\title{
Dynamic Viscoelastic Properties of Crystalline Polymer Blends Effect of the Viscosity of Domain Phase -
}

\author{
Hisahiko KASHIHARA $^{* 1,2}$, Masaoki TAKAHASHI ${ }^{* 3}$, Kenji URAYAMA ${ }^{* 1}$, and Toshikazu TAKIGAWA ${ }^{* 1}$ \\ ${ }^{* 1}$ Department of Material Chemistry, Kyoto University, Nishikyo-ku, Kyoto 615-8510, Japan \\ ${ }^{* 2}$ Minase Research Laboratories, Sekisui Chemical Co., Ltd., Mishima-gun, Osaka 618-8589, Japan \\ ${ }^{* 3}$ Department of Polymer Science and Engineering, Kyoto Institute of Technology, Sakyo-ku, Kyoto 606-8585, Japan
}

\begin{abstract}
We investigated the influence of viscoelasticity of the domain phase on that of the polymer blend. The polyethylene (PE, matrix phase)/polypropylene (PP, domain phase) blend was used and the viscoelastic change was measured on condition that PP alone crystallizes. The modulus of domain phase was lower than that of matrix phase at first, but was much higher when PP was completely crystalized. The average domain size was almost the same before and after the test. The storage modulus at low frequencies increased more rapidly than that at high frequencies, and then the former decreased and the latter increased continuously. These changes are almost understood by Palierne's emulsion model. Recovery from deformation of domain phase effectively makes long-time viscoelastic relaxation when the modulus of domain phase is close to or lower than that of matrix phase.
\end{abstract}

Key Words: Crystallization / Polymer blend / Dynamic viscoelasticity / Emulsion model / Relaxation time

\section{分散相粘度が結晶化によって変化するポリマーブレンドの動的粘弾性}

\author{
柏原 久彦 ${ }^{* 1,2}$, 高橋 雅興 ${ }^{* 3}$, 浦山 健治 ${ }^{* 1}$, 瀧川 敏算 ${ }^{* 1}$
}

(原稿受理：2004年5月27日）

\section{1. 緒言}

ポリマーブレンド溶融物の粘弾性挙動については, 数多く の実験的および理論的考察がなされてきた. ${ }^{1,2}$ 一つの相が他 の相に分散した系を考える場合, (i) 分散相の存在が連続相に どんな効果をもたらすか, (ii)応力と変形速度がどのように分 散相の分布, 形態, 配向に影響するか, (iii) 界面効果とは何 か, (iv)測定される応答に対する(i) (iii)の影響は何か, これら を説明できれば，測定量の意味が理解できるとUtrackiは述べ ている. ${ }^{1)}$ 分散相が球形で分散しているポリマーブレンド溶 融物の線形粘弾性については, Palierneのエマルションモデル

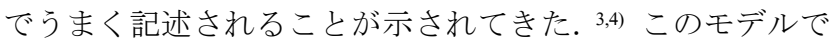
は, 連続相や分散相単独では存在しない長時間緩和を, 分散 相の変形とその回復を考慮することで説明している. また, 剛体粒子分散系で発現する長時間緩和は，粒子の並進拡散の 位置回復によって表されることを四方らが示している. ${ }^{5,6} こ$ れらのことから推しはかると, 分散相の粘度が連続相のそれ よりも低いか同程度のときには分散相の変形が, 逆に分散相 の粘度が連続相のそれよりも高い時には分散相の並進拡散 がブレンドの長時間緩和を支配することになる．分散相の大

*1 京都大学大学院工学研究科

*2 積水化学工業㑣水無瀬研究所 $\overline{7} 618-8589$ 大阪府三島郡島本町百山

Tel: 075-962-8813,Fax: 075-961-5353,E-mail: kashihara@sekisui.jp

*3 京都工芸繊維大学繊維学部
きさや分散状態を一定に保ったままで分散相の硬さだけを 大きく変化させるような実験が可能であれば，ブレンド系特 有の長時間緩和について, これまでよりも詳細な情報が得ら れる.しかし, 通常のポリマーブレンドでは, 分散相と連続 相との粘度比が分散径や分散状態を大きく恋化させる7)ため, このような実験系を実現することは難しかった. 本研究では, ポリエチレン（連続相）／ポリプロピレン（分散相）ブレン ドを試料として用いて，分散相であるポリプロピレンのみが 結晶化するような温度下におくことで，分散状態を保ったま ま分散相の粘弾性だけを変化させた。この間の動的粘弾性関 数を測定することで, 分散相の粘弾性がブレンド全体の粘弾 性に与える影響について検討した結果について報告する．工 業的にも, 成形時などの冷却過程における結晶性ポリマーブ レンドの流動性をとらえる上で有用な知見となりうる.

\section{2. 実験}

試料として, 低密度ポリエチレン（PE，メルトインデック ス：55g/10分）とポリプロピレン（PP，ホモポリマー，メル トフローレート : $330 \mathrm{~g} / 10$ 分）を用いた. 東洋精機製作所製ラ ボプラストミルを用いて, $190^{\circ} \mathrm{C}, 40$ 回転で, 7分間, 溶融混 練し，熱プレスにより円板状試料に成形することでブレンド 試料を得た．ブレンド比は重量比でPE/PPが3/1である.

動的粘弾性の測定には, レオメトリック・サイエンティ 
フィック・エフ・イー製RMS 800 を使用した。 直径 $25 \mathrm{~mm}$ の平 行円板型の治具を用い, 試料の厚さを約 $0.9 \mathrm{~mm}$, 外周部のひ ずみ振幅を $0.2 \sim 0.25$ として測定した. まず試料を $180^{\circ} \mathrm{C} て ゙ 5$ 分 間保持することにより，熱および結晶の履歴を消去した，そ の後, 約 15 分かけて $130^{\circ} \mathrm{C}$ まで泠却し, 同温度で保持しなが ら粘弾性測定を行うことで, 分散相粘度が結晶化によって変 化するポリマーブレンドの動的粘弾性を評価した。試料の変 化をできる限り抑えるため, 窒素気流下にて測定を実施して いる. なお, $130^{\circ} \mathrm{C}$ という温度は, 今回用いた $\mathrm{PE}$ 融点以上 であり，分散相であるPPのみが結晶化できる温度である。

測定方法の説明のために, 一連の粘弾性測定における温度 と貯蔵剛性率 $\left(G^{\prime}\right)$, 損失剛性率 $\left(G^{\prime \prime}\right)$ の変化を, Fig.1に示し た. 分散相であるPPを結晶化させる時間 $(t)$ の基準として, 温度が $130^{\circ} \mathrm{C}$ になった時間を $t=0$ と決めた. $180^{\circ} \mathrm{C}$ での保持中 および $130^{\circ} \mathrm{C}$ への冷却中である $t=0$ 以前も, 周波数 $(\omega)$ が $1 \mathrm{~s}^{-1}$

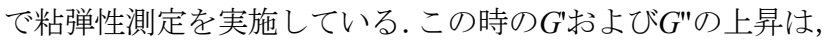
温度低下によるものであり, PP相の結晶化によるものではな い. 温度が $130^{\circ} \mathrm{C}$ となった $t=0$ 以降では, $\omega$ を $100 \mathrm{~s}^{-1}$ から $0.0631 \mathrm{~s}^{-1}$ まで掃引させながら，17の心で $G^{\prime}$ と $G^{\prime \prime}$ を測定してい る. 低いのほど測定に時間を要するので, 測定ごとの閒隔は 広がっている。

PE, PP単独の試料についても, 溶融混練, 熱プレスを経た 試料とし, $180^{\circ} \mathrm{C}$ で5分の熱処理後に溶融状態での粘弾性を評 価した. PPの結晶化完了後の粘弾性については, 同様の試料 をプレス機中で $180^{\circ} \mathrm{C}$ で一旦溶融させ, その後 $130^{\circ} \mathrm{C}$ で結晶化 させた固体試料を用いて, レオメトリック・サイエンティ フィック・エフ・イー製RSA IIにて，引っ張りモード，ひず み振幅 $0.1 \%$ で測定を行った.

PE/PPブレンドの相構造観察には日立製作所製の電界放射 型走查電子顕微鏡S-4500を用いて, 試料断面のPPの分散状態 を評価した. PPの分散径の統計的評価には, 画像処理装置を 用いて，断面を円と見なした際の半径を度数解析することで 行った.

\section{3. 結果と考察}

粘弾性変化を論じる前に, 相構造について述べる. Fig.2に, 粘弾性測定前後での試料中央付近断面の電子顕微鏡写真の

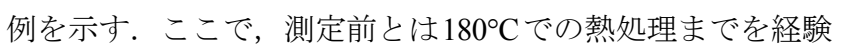
した試料のことである. 測定後とは, $130^{\circ} \mathrm{C} て ゙$ 保持してPP相 を結晶化させながら粘弾性測定を実施した試料のことであ る. 暗い部分がPP相を, 明るい部分がPE相を表しており, PP 相がほぼ球形で分散していることがわかる. PP相の分散径を 統計的に解釈するために, 断面写真に現れる円の半径の出現 頻度を評価した結果を Fig. 3 に示す. 半径が $0.25 \mu \mathrm{m}$ 以上の約 2000個のPP相についての処理結果であり, 横軸は断面の円の 半径, 縦軸は出現割合を表す. 大きさの分布に若干の差があ るが, 測定前後でほぼ同じと見なせると考える. 断面の円が 球の一部であるとして, $\overline{r_{\mathrm{s}}}=(9 \pi / 32) \overline{R_{\mathrm{v}}}$ に従って球である $\mathrm{PP}$ 相

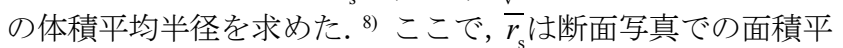
均半径, $\overline{R_{\mathrm{v}}}$ は実際に分散している球の体積平均半径を表す。 Fig.3の中にも示したが, PP相の体積平均半径が, 粘弾性測定 前の試料で $3.7 \mu \mathrm{m}$, 粘弾性測定後の試料で $3.8 \mu \mathrm{m}$ とほとんど変 化なかった. このことから, 粘弾性測定中による分散構造の 変化は小さく, 分散構造を保ったままで分散相の粘度だけを
変化させることを実現できていると考えられる.

Fig.4に，連続相を構成するPEと分散相を構成するPP の $130^{\circ} \mathrm{C}$ における貯蔵剛性率 $G$ と損失剛性率 $G^{\prime \prime}$ を示す。PEおよ び結晶化前のPPの $G^{\prime}, G^{\prime \prime}$ は，180，160，140，130および $120^{\circ} \mathrm{C}$ $\left(120^{\circ} \mathrm{C}\right.$ はPEのみ) の $G^{\prime}, G^{\prime \prime}$ から時間-温度換算則を用いて求

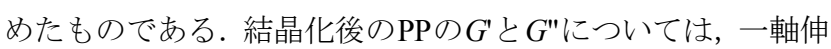
長変形を与えて測定した引つ張りの動的弾性率 $E$, $E^{\prime \prime}$ から, $G=E /\{2(1+\mu)\}\left(G: G^{\prime}, G^{\prime \prime}, E: E^{\prime}, E^{\prime \prime}\right)$ として計算したものであ

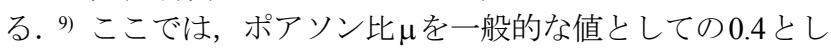
た. Fig.4からわかるように, PPが結晶化する前は分散相の粘

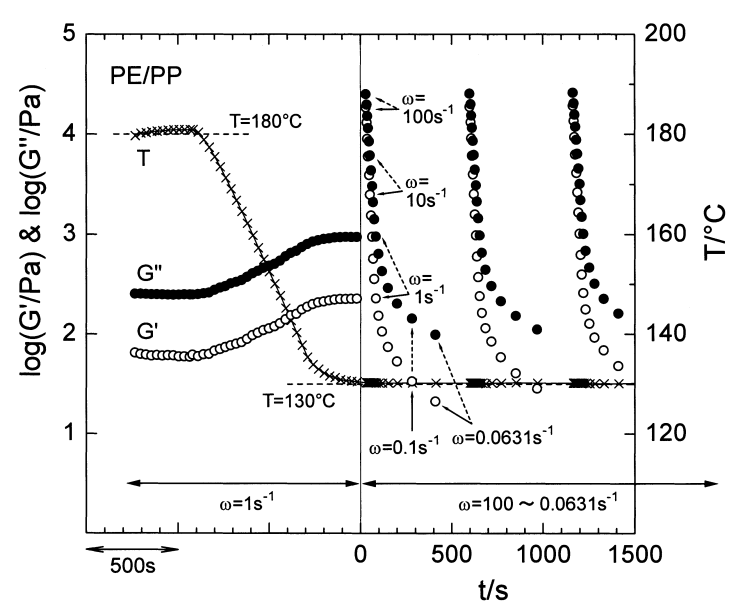

Fig.1 The change of temperature and viscoelastic function from annealing at $180^{\circ} \mathrm{C}$ to measurement at $130^{\circ} \mathrm{C}$. (a)

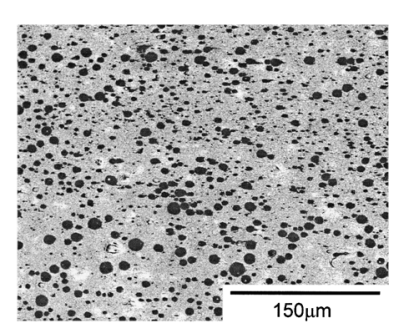

(b)

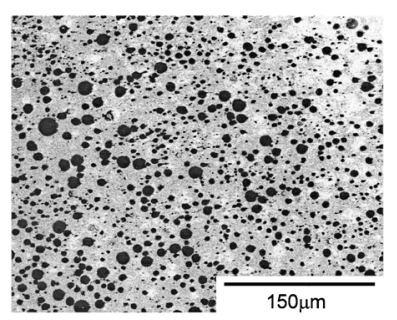

Fig.2 Scanning electron micrographs (a) before and (b) after the dynamic viscoelastic measurement at $130^{\circ} \mathrm{C}$.

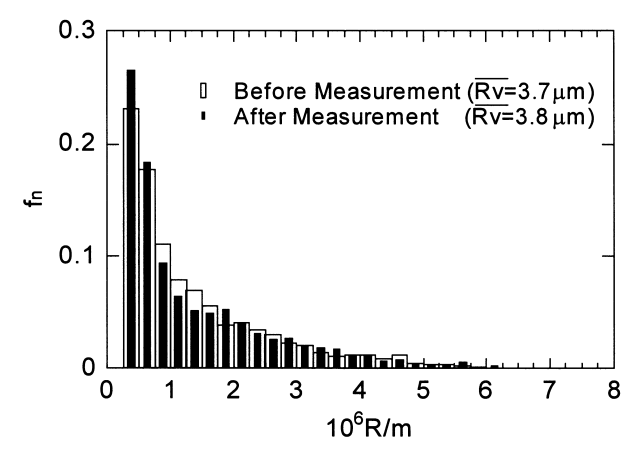

Fig.3 Distribution of the droplet radius before and after the dynamic viscoelastic measurement. The ordinate indicates the number fraction of the droplets. 
度が連続相のそれよりも低いが，結晶化が進行することで分 散相の粘度が連続相のそれよりもはるかに高くなる，例え ば, $1 \mathrm{~s}^{-1}$ の周波数で見ると, 結晶化前の分散相の $G^{\prime}$ は連続相 の約 $1 / 3$ であるが，結晶化完了後には連続相の $3 \times 10^{5}$ 倍にもな る. 結晶化前の分散相は, 連続相と同様に, 低周波数側でlog $\omega$ と $\log G^{\prime \prime}$ とが傾き 1 の直線関係で表されており，典型的な高 分子液体の曲線である. 一方, 結晶化後の分散相は $G^{\prime}, G^{\prime \prime}$ の 周波数依存性がほとんどなく, 典型的な固体の粘弾性曲線と いえる. 分散相は, 連続相よりも軟らかい液体から連続相よ りはるかに硬い固体へと, 時間の経過で変化することになる.

Fig.5に, それぞれの周波数における， $G^{\prime}$ と $G^{\prime \prime}$ の時間変化を 示した. $G^{\prime \prime}$ は, 周波数によらず時間の経過によってほぼ単調 に増加し続ける. 一方, $G^{\prime}$ は, $1 \mathrm{~s}^{-1}$ 以上の周波数では $G^{\prime \prime}$ と同 様に単調に増加するが, $0.3981 \mathrm{~s}^{-1}$ 以下の低周波数領域では, 一 旦上昇した後, 低下に転じた。この挙動をより詳細に解析す るために，ある時間 $t$ での周波数依存性曲線を作成した．時間 $t$ に対応する $G^{\prime}, G^{\prime \prime}$ は, それぞれの周波数で, その時間の前後 で測定した $G^{\prime}, G^{\prime \prime}$ から内挿して求めた。 Fig.6に， $t$ が420s, $1800 \mathrm{~s} ， 4800 \mathrm{~s}$ および $18000 \mathrm{~s}$ の時の $G^{\prime}, G^{\prime \prime}$ の周波数依存性を示 す。それぞれのグラフは，見やすいように縦軸方向に図中に 記載したAだけ動かして表示している。また，連続相である PEの曲線もついても比較のために書き入れた. ここで, $t=420 \mathrm{~s}$ は, PPがほとんど結晶化していない状態であり, $t=18000$ sは, PPの結晶化が完了している状態と推測される. まず, $t=420 \mathrm{~s}$ の時の曲線に注目する. この時, 分散相は連続相より柔らか いはずであり，このことを反映して $1 \mathrm{~s}^{-1}$ 以上の高周波数側で は, 系の剛性率は連続相のそれより低くなっている. $1 \mathrm{~s}^{-1} よ$ り低い周波数領域では, 連続相を構成するPE単体では見られ ない長時間緩和が低周波数側のショルダーとして現れてい るため, PEの剛性率よりも大きくなっている. 詳細は後述す るが, この緩和は, 分散相の変形回復によるものである.こ のような長時間緩和はよく見ると $G^{\prime \prime}$ の曲線にも存在してい るが, $G^{\prime}$ のほうが緩和の存在に敏感であるためでより明確で ある. 時間が経過し, $t=1800 \mathrm{~s}$ では, 高周波数側の $G^{\prime}$ よび $G^{\prime \prime}$ が連続相のそれらと同等程度にあることから, 分散相と連続 相の剛性率はほぼ等しくなっていると思われる。この時も, 分散相の変形回復にともなう緩和は $G^{\prime}$ の曲線に明確に現れて いる. 以後, 時間が経過するにつれてPPの剛性率は高くなり, 高周波数側の弾性率はPE単体よりも高くなる. また, それと 共に，先に見られた長時間緩和については消失していくこと がわかる.このような長時間緩和の変化と消失が, Fig. 5 で見 られたような $G, G^{\prime \prime}$ の時間変化を引き起こすといえる.

ここで, エマルションモデルを用いて, 上述した長時間緩 和について詳細に考える3,4)こととする. 変形回復の緩和時間 $\left(\tau_{\mathrm{d}}\right)$ と緩和強度 $\left(G_{\mathrm{d}}\right)$ は,

$$
\begin{aligned}
& \tau_{d}=\frac{R \eta m}{4 \alpha} \frac{(19 K+16)(2 K+3-2 \phi(K-1))}{10(K+1)-2 \phi(5 K+2)} \\
& G_{d}=\frac{20 \alpha \phi}{R} \frac{1}{(2 K+3-2 \phi(K-1))^{2}}
\end{aligned}
$$

で表される．ここで，Rは分散相の半径， $\eta_{\mathrm{m}}$ は連続相の粘度， $\alpha$ は界面張力, $K$ は分散相の粘度と連続相の粘度の比 $\left(\eta_{\mathrm{d}} / \eta_{\mathrm{m}}\right)$, $\phi$ は分散相の体積分率である. $R$ は体積平均半径で代表させる

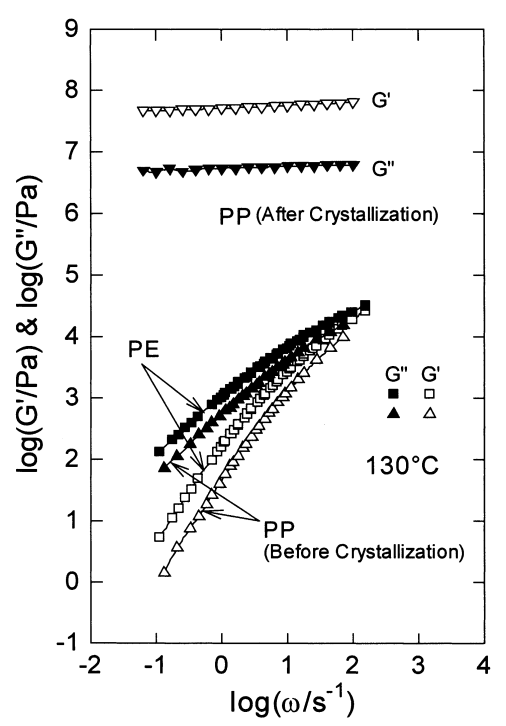

Fig.4 Dynamic viscoelastic functions of PE (matrix phase) and PP (domain phase, before and after crystallization) at $130^{\circ} \mathrm{C}$. (a)

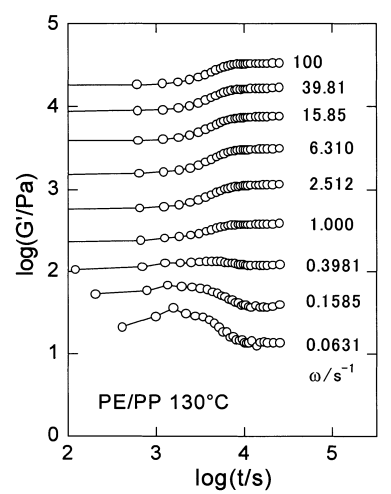

(b)

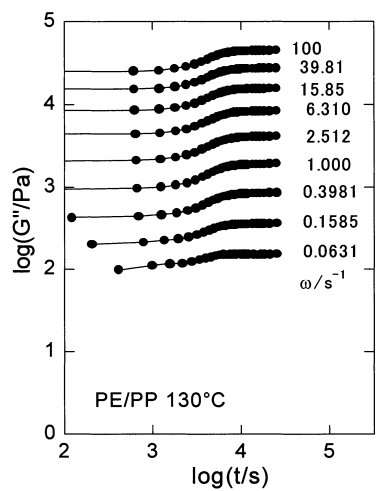

Fig.5 Time dependence of (a) storage and (b) loss modulus at various frequencies during crystallization of PP phase. (a)

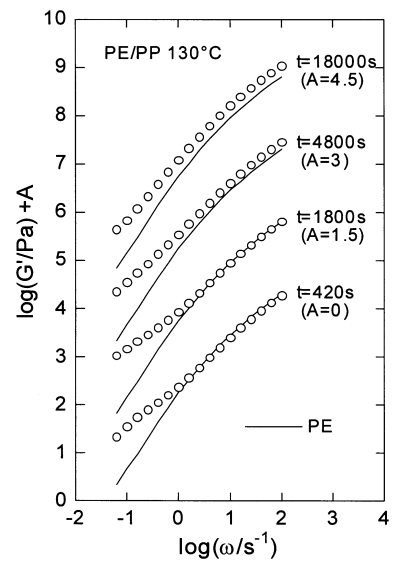

(b)

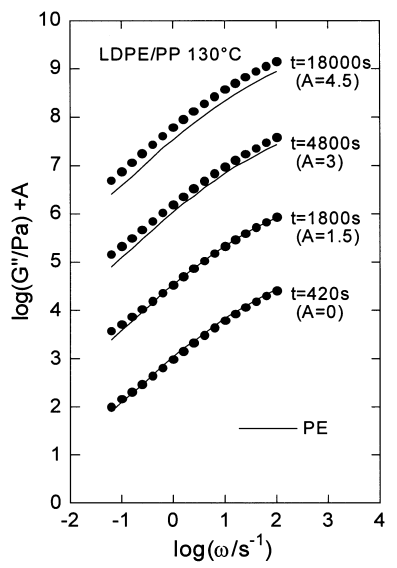

Fig.6 Frequency dependence of (a) storage and (b) loss modulus at various times during crystallization of PP phase. 
ことができる。 ${ }^{4}$ 今回の実験系では, 連続相, 分散相ともに ニュートン液体ではないので $\eta_{\mathrm{m}}$ および $\eta_{\mathrm{d}}$ を直接求めることは できないが, 連続相のPEや結晶化前のPPでは $1 \mathrm{~s}^{-1}$ 以下の周波 数で $G^{\prime}<G^{\prime \prime}$ でありかつ $G^{\prime \prime}$ が周波数の一乗にほぼ比例している ことから，G"G低周波数領域の值を用いてこれらに相当する 值を決めることができる. $\alpha$ は類似した実験系でのデータか ら $1.1 \mathrm{~N} / \mathrm{m}$ とし ${ }^{10)}, \phi$ PP, PEの溶融状態での比重が等しいと して, 重量分率と同じ 0.25 とした. したがって, $\tau_{\mathrm{d}}$ と $G_{\mathrm{d}}$ が計 算可能である.

PPが結晶化する前の $t=0$ では, $\tau_{\mathrm{d}}$ は $8.83 \times 10^{\circ} \mathrm{s}, G_{\mathrm{d}}$ は $8.49 \times 10^{1} \mathrm{~Pa}$ となる. Fig.6の $G^{\prime}$ の曲線において, 周波数が $\tau_{\mathrm{d}}^{-1}$, すなわち $1.13 \times 10^{-1} \mathrm{~s}^{-1}$ と, $G^{\prime}$ が $G_{\mathrm{d}}$ の $8.49 \times 10^{1} \mathrm{~Pa}$ は, ちょうどショルダーに あたる部分であり, $t=0$ で系に発現する長時間緩和は変形回復 によるものといえる，ここで，式(1), 式(2)に従って，Kが変 化する場合の $\tau_{\mathrm{d}}^{-1} と G_{\mathrm{d}}$ の変化の計算結果を, Fig.7 7 示す. PP

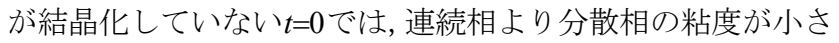
く,Kは0.4557である. 時間の経過につれて, Kは大きくなる 方向であり, Fig.7から読み取れるように， $\tau_{\mathrm{d}}^{-1}$ と $G_{\mathrm{d}}$ は共に小 さくなっていくことになる. 実際の実験系では分散相の粘度 が単純に増加するだけでなく弾性成分も大きくなっていく ので, Kが単純に大きくなるとはいえない. しかし, 変形回 復に関する長時閒緩和の変化については，この計算結果と同 じ挙動と考えて良い. 実際, Fig.6での $G$ および $G^{\prime \prime} の$ 周波数依 存性曲線の変化は, この考え方に合うものであり, 曲線に現 れるショルダーの位置は, 時間の経過と共に低周波数側へか つ低剛性率へ移動している. なお, Fig.6で結晶化が完了した $t=18000 \mathrm{~s}$ においても, $1.5 \times 10^{-1} \mathrm{rad} / \mathrm{s}$ 以下の周波数域に $G^{\prime}$ にショ ルダーがあるように見えるが，これは測定中の熱による連続 相のPEの変化によるものと考えられる.PE単独で同様の粘弾 性測定を実施した場合も, 低周波数域での $G^{\prime}$ の昇が観察さ れる. 熱による分子量増加や架橋の影響であろう。 $G^{\prime \prime}$ 同様 に上昇するが， $G^{\prime}$ ほど顕著ではない.

エマルションモデルから(3)式に従って, $t=420 \mathrm{~s}$ と $t=18000 \mathrm{~s}$ の場合の系の粘弾性関数を計算した結果をFig.8に示す.

$$
\begin{gathered}
G^{*}(\omega)=G^{*} M(\omega) \frac{1+3 \phi H(\omega)}{1-2 \phi H(\omega)} \\
H(\omega)=\left\{4(\alpha / R)\left(2 G^{*} M(\omega)+5 G^{*} D(\omega)\right)+\right. \\
\left.\left(G^{*} D(\omega)-G^{*} M(\omega)\right)\left(16 G^{*} M(\omega)+19 G^{*} D(\omega)\right)\right\} \\
\left\{40(\alpha / R)\left(G^{*} M(\omega)+G^{*} D(\omega)\right)+\right. \\
\left.\left(2 G^{*} D(\omega)+3 G^{*} M(\omega)\right)\left(16 G^{*} M(\omega)+19 G^{*} D(\omega)\right)\right\} \\
G^{*}(\omega)=G^{\prime}(\omega)+i G^{\prime \prime}(\omega)
\end{gathered}
$$

ここで, $G^{*}{ }_{\mathrm{M}}, G_{\mathrm{D}}^{*}$ は, それぞれ, 連続相, 分散相単独での複 素剛性率を表す. 各周波数における $G^{\prime}$ と $G^{\prime \prime}$ の值は, 前後の周 波数の值から内挿して求めた. Fig.4のマスターカーブの範囲を 超えた周波数での值については外挿して求めたが, 外挿值を 使用して計算した部分は，Fig.8では破線で表示してある.ま た， $t=18000$ sにおける連続相であるPEの $G^{\prime}, G^{\prime \prime}$ の值は, Fig.4 の值ではなく, $t=18000 \mathrm{~s}$ と同じ熱履歴を経験した別の実験での 值を用いた. 先に述べたように，熱によるPEの変化を考慮す るためである.分散相の変形回復による緩和が存在する $t=420 \mathrm{~s}$ の場合, 測定範囲内にはこのような特別な緩和が存在しない $t=18000 \mathrm{~s}$ の場合の両方ともうまく記述できているといえる.
この系における並進拡散の位置回復に基づく長時間緩和 の緩和時間を計算した 5 ,6) ところ，105 $\mathrm{s} 10^{6} \mathrm{~s}$ のオーダーである とされた.今回の実験で測定した周波数の範囲では観測され ないものと思われる.

\section{4. 結 論}

ポリマーブレンド中における分散相の粘弾性が系の粘弾 性およぼす影響について調べることを目的として，分散相 （PP）だけが結晶化し，連続相（PE）より柔らかい状態から それより硬い状態へと変化する状態での粘弾性挙動につい て検討した．結果をまとめると次のようになる.

1) 低周波数側の $G^{\prime}$ は一旦上昇して低下したが， $G^{\prime \prime}$ と高周波 数側の $G^{\prime}$ は単調に増加した。

2)このような挙動は分散相の変形回復に伴う長時間緩和 がどのようにふるまうかで説明でき，エマルションモデル がこれをうまく記述する. この長時間緩和は, 分散相が連 続相よりも柔らかいか同程度であるときに最も顕著に観 察される。

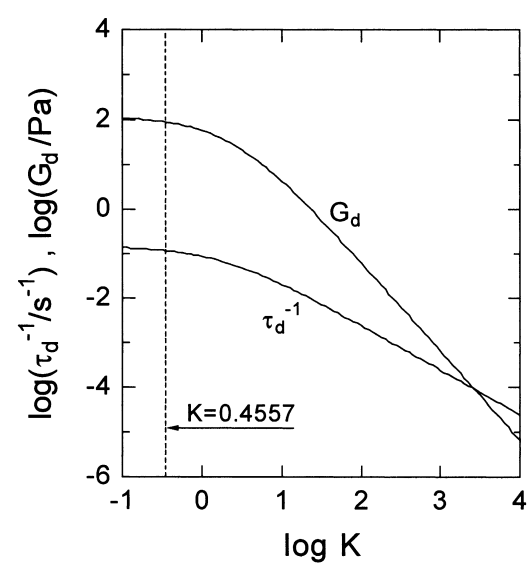

Fig.7 The change of relaxation time and relaxation strength at various domain-matrix viscosity ratio predicted by emulsion model. The ratio increases by the crystallization of PP phase.

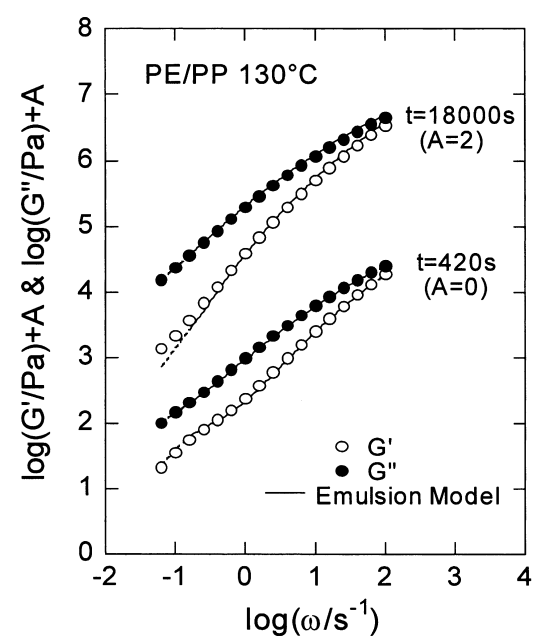

Fig.8 Frequency dependence of viscoelastic functions at 420 s and 18000s. The Lines represent the prediction by emulsion model. 


\section{REFERENCES}

1) Utracki LA, "Polymer Alloys and Blends Thermodynamics and Rheology", (1989), Carl Hanser Verlag, New York, Chap.3. Utracki LA, "Porima Aroi to Porima Burendo", trans. Nishi T, (1991), Tokyo Kagaku Dojin, Tokyo, Chap.3.

2) Masuda T, "Porima Aroi - Kiso to Oyou, 2nd Ed", ed. Kobunshi Gakkai, (1993), Tokyo Kagaku Dojin, Tokyo, Chap.7.

3) Palierne JF, Rheol Acta, 29, 204 (1990).

4) Graebling D, Muller R, Palierne JF, Macromolecules, 26, 320 (1993).

5) Shikata T, Pearson DS, J Rheol, 38, 601 (1994).
6) Masuda T, Takigawa T, Ohta Y, Annual Report of Research Institute for Chemical Fibers, 45, 17 (1988).

7) Mans-Zloczower I, Tadmor Z, "Mixing and Compouding of Polymers", (1994), Carl Hanser Verlag, New York, Chap.4.

8) Okamoto K, Takahashi M, Yamane Y, Kashihara H, Watanabe H, Masuda T, J Rheol, 43, 951 (1999).

9) Masuda T, “Kouza Reoroji”, ed. Nihon Reoroji Gakkai, (1992), Kobunshi Kankokai, Kyoto, Chap.1.

10) Wu S, "Polymer Handbook, 3rd Ed" (1989), John Wiley \& Sons, New York, Chap.4. 